\title{
Expression of Some Pro-inflammatory Cytokines and Inflammatory Mediators in Experimental Model of Trichinella Spiralis
}

\author{
Nema A. Soliman *, Noha M. Shafik*, Zeinab S. Shoheib *, \\ Dalia S. Ashour* \\ * Medical Biochemistry, *Medical Parasitology Departments, \\ Faculty of Medicine, Tanta University,
}

\begin{abstract}
Trichinellosis is a zoonosis acquired by the ingestion of undercooked meat containing the infective larvae of Trichinella spiralis (T. spiralis). Despite veterinary public health efforts to control it, re-emergence of the disease has been observed in many areas of the world in the past 10-20 years. Although ivermectin (IVM) achieved high efficacy as larvicidal in trichinellosis, the possibility of disease transmission to other hosts is still present that will hinder the eradication of that serious disease. Therefore, our goal is to determine the efficacy of IVM on the subsequent infectivity of T. spiralis larvae in experimental animals through parasitological and biochemical studies of the intestinal phase. We found that the proinflammatory cytokine; interleukin-1 $\beta$ (IL$1 \beta$ ) and epithelial neutrophil activating peptide 78 (ENA-78) mRNA expression were decreased in group II which was infected by IVM-treated T. spiralis larvae on the $5^{\text {th }}$ day post infection, also the same group showed the lowest levels of vasoactive intestinal peptide (VIP) and protein carbonyl (PCO) as well as the lowest activities of myeloperoxidase (MPO) and superoxide dismutase (SOD) enzymes. The lowest adult and larval counts were observed in group II at the $5^{\text {th }}$ day post infection with highly significant differences in comparison to other groups. In conclusion, IVM appears to affect the infectivity of $T$. spiralis larvae with subsequent decrease of T. spiralis adults and total larval count. These effects were more pronounced when IVM was given early in the infection. IVM is feasible and useful drug in the treatment of current infection and control of subsequent infections with T. spiralis.
\end{abstract}

Keywords: Trichinella spiralis, ivermectin (IVM), larval infectivity, proinflammatory cytokines, vasoactive intestinal peptide (VIP), protein carbonyl (PCO), superoxide dismutase (SOD).

\section{INTRODUCTION}

Trichinellosis is a zoonosis acquired by the ingestion of undercooked meat containing the infective larvae of Trichinella spiralis (T. spiralis). Trichinellosis continues to be a public health concern throughout the world. It has been estimated that 11 million people worldwide could be infected (1). Despite veterinary public health efforts to control and eradicate the parasite, re-emergence of the disease has been observed in many areas of the world in the past 10-20 years. 
Therefore, appropriate control for this zoonotic disease should always be maintained in all districts ${ }^{(2)}$.

Ivermectin (IVM) is a broadspectrum antiparasitic drug widely used to control a wide range of gastrointestinal helminthes ${ }^{(3)}$. IVM acts by binding to a glutamate-gated chloride channel receptor (GluCls) in nematode and arthropod nerve cells, and also increases the release of gamma-aminobutyric acid (GABA) from synaptosomes of the nervous system and blocks the transmission of nervous stimuli to muscles resulting in flaccid paralysis of the affected parasites, followed by their death or expulsion ${ }^{(4)}$. Although IVM achieved high efficacy as larvicidal in trichinellosis reaching about $83 \%$, the possibility of $T$. spiralis transmission to other hosts is still present that will hinder the control and eradication of trichinellosis ${ }^{(5)}$.

Epithelial cells are the first site of entry for invasive intestinal pathogens and may provide early signals for the acute mucosal inflammatory response via the release of proinflammatory cytokines and inflammatory mediators $^{(\mathbf{6})}$. The prototypic proinflammatory cytokine; interleukin-1 $\beta$ (IL-1 $\beta$ ) is released by activated immune cells and it was found to be increased in the mucosa of patients with inflammatory bowel disease $^{(7)}$ and in the inflamed intestine in animals ${ }^{(8)}$. Epithelial neutrophilactivating peptide 78 (ENA-78) is one of the chemokines which are a family of small cytokines, or proteins secreted by cells. They induce directed chemotaxis in nearby responsive cells, and their expression has been shown to be highly inducible in endothelial and vascular smooth muscle cells by IL-1 $\beta$ and tumor necrosis factor-alpha ${ }^{(9)}$.

Both the central nervous system (CNS) and the enteric nervous system (ENS) can amplify or modulate aspects of intestinal inflammation through secretion of neuropeptides that serve as a link between the ENS and CNS. Neuropeptides are defined as any peptide released from the nervous system that serves as an intercellular signaling molecule. They include substance $\mathrm{P}$, corticotropinreleasing hormone, neurotensin, vasoactive intestinal peptide (VIP), mucopioid receptor agonists, and galanin $^{(\mathbf{1 0})}$. VIP exhibits broad significance in intestinal physiology because of its potent vasodilator actions $^{(11)}$. It also govern regulation of motility, inhibit the peristaltic reflex in the circular smooth muscle layer, control intestinal blood flow, and modulate the immune system ${ }^{(\mathbf{1 2})}$. This VIP is released from nerve terminals with enzymes of the nitric oxide (NO) synthesis cascade in the myenteric plexus ${ }^{(13)}$.

The biological damage caused by free-radical-mediated mechanisms can be prevented by specific chemical scavengers which trap the specific radicals, as well as by protective antioxidant enzymes including superoxide dismutase (SOD) ${ }^{(\mathbf{1 4})}$. SOD catalyzes the dismutation of superoxide into oxygen and hydrogen peroxide. Hence, it acts as a cornerstone antioxidant defense mechanism in nearly all cells exposed to oxygen oxidative stress ${ }^{(15)}$. Protein carbonyl (PCO) groups formation is generated by covalent modification of a protein either directly by reactive 
oxygen species (ROS) or indirectly by reaction with secondary by-products of oxidative stress, the usage of PCO as biomarkers of oxidative stress has some advantages in comparison with the measurement of other oxidation products because of the relative early formation and the relative stability of carbonylated proteins ${ }^{(\mathbf{1 6})}$. Myeloperoxidase (MPO) is found predominantly in neutrophils used as a quantitative index of inflammation due to the correlation between MPO activity and neutrophil infiltration in the intestine ${ }^{(\mathbf{1 7})}$. Therefore, MPO activity has been widely used to detect and follow intestinal inflammatory processes, and a reduction in its activity can be interpreted as a manifestation of the antiinflammatory activity of a given $\operatorname{drug}^{(18)}$.

The goal of the present study is to compare the efficacy of IVM, given on two different periods post $T$. spiralis infection, on the subsequent infectivity of $T$. spiralis-treated larvae in experimental animals as a possible method for $T$. spiralis control in pig farms. This effect on infectivity was assessed by both parasitological and biochemical studies of the intestinal phase.

\section{MATERIAL \& METHODS}

\section{Animals and T. spiralis infection:}

Laboratory-bred parasite free, Swiss albino mice weighing 18-20 grams each, were used in the present study. Experimental animals were obtained from the animal house of Theodore Bilharz Research Institute (TBRI), Giza, Egypt. Mice were fed on a standard pellet diet containing 24
$\%$ protein, $4 \%$ fat and about $4-5 \%$ fiber in addition to water ad libitum, in accordance with the institutional and national guidelines. The isolate of T. spiralis used was originally obtained from infected pork meat from Cairo abattoir and maintained in the laboratory of Medical Parasitology Department, Tanta Faculty of Medicine by consecutive passages through rats and mice. Mice were infected with $T$. spiralis larvae in a dose of 250 larvae/ mouse orally according to Dunn and Wright [Dunn et al., 1985] ${ }^{(\mathbf{1 9 )}}$. All animal procedures reported herein were reviewed and approved by the Research Ethics Committee, Quality Assurance Unit, Faculty of Medicine, Tanta University.

Drug administration: Ivermectin (Iverzine ${ }^{\circledR}$, UNI Pharma) was used in a single oral dose of $0.2 \mathrm{mg} / \mathrm{kg}$ body weight, using distilled water as a solvent.

Experimental design and sampling: The experiment was done in two phases:

Phase 1: included 3 groups of animals (10 mice each) infected by $T$. spiralis larvae; group A: infected untreated, group B: infected and treated with IVM on the $5^{\text {th }}$ day post infection (d.p.i.), and group C: infected and treated with IVM on the $10^{\text {th }}$ d.p.i.

Phase 2: the larvae obtained from each of the previous groups on the $35^{\text {th }}$ d.p.i. were used to infect another three groups of mice (45 mice each); group I: included mice infected with larvae from $T$. spiralis infected untreated mice (group $A$ in phase 1), group II: included mice infected with larvae from $T$. spiralis infected mice that were treated with IVM on 
the $5^{\text {th }}$ d.p.i. (group B in phase 1), and group III: included mice infected with larvae from $T$. spiralis infected mice that were treated with IVM on the $10^{\text {th }}$ d.p.i (group $C$ in phase 1). All mice were infected by 250 larvae/ mouse. On the $5^{\text {th }}$ and $12^{\text {th }}$ d.p.i., 15 mice from each infected group were sacrificed by cervical dislocation. Those represent subgroups: $\mathrm{a}, \mathrm{b}$ respectively according to time of scarification. The small intestine of each mouse was removed, opened longitudinally, washed and one piece of the middle third was stored at $-80^{\circ} \mathrm{C}$ for biochemical studies. T. spiralis adult count was done in the rest of the small intestine. On $35^{\text {th }}$ d.p.i. the remaining 15 mice from each group were sacrificed and their muscles were digested for larval count (subgroup c). Another 15 uninfected untreated mice were used in the $2^{\text {nd }}$ phase to serve as the negative control group (group IV), which were sacrificed once at the end of the experiment.

T. spiralis adult count in the intestine: The washed intestine was cut into small pieces $1 \mathrm{~cm}$. each, and then incubated at $37^{\circ} \mathrm{C}$ in $10 \mathrm{ml}$. saline for 2 hours to allow the worms to migrate and collect in the container. The saline was pipetted and the intestine was washed several times with saline. All of the fluid was collected in tubes and centrifuged at $1500 \mathrm{rpm}$ for 5 minutes. The supernatant was decanted and the sediment reconstituted in 3-5 drops of saline to be examined drop by drop at a magnification of X 20 and the adult worms were counted ${ }^{(20)}$.

T. spiralis encysted larval count in the muscles: Each mouse was dissected and digested in $1 \%$ pepsin and $1 \%$ concentrated $\mathrm{HCl}$ in 200 c.c. distilled water. The mixture was incubated at $37^{\circ} \mathrm{C}$ for one hour under continuous agitation using an electric stirrer. The digested product was passed through a 50-mesh/ inch sieve to remove the coarse particles. Encysted larvae were collected on a 200-mesh/ inch sieve, washed twice with tap water and then suspended in 150 c.c. of tap water in a conical flask. The supernatant fluid was then discarded and the larvae in the sediment were counted microscopically using a McMaster counting chamber ${ }^{(21)}$.

Estimation of levels of $I L-1 \beta$ and ENA-78 mRNA expression by semiquantitative real-time PCR: Parts of intestinal tissue samples were processed for total RNA extraction, (MagNA Pure compact Nucleic Acid isolation kit I, Roche Diagnostics, $\mathrm{GmbH}$, Mannheim, Germany) according to the manufacturer's recommendations. First strand cDNA was synthesized from total RNA using Transcriptor First Strand cDNA Synthesis Kit (Roche, Germany) according to the manufacturer's instructions. IL-1 $\beta$ and ENA-78 mRNA transcripts were quantified, relative to the house-keeping gene; glyceraldehyde-3-phosphate

dehydrogenase (GAPDH) using the Roche LightCycler® FastStart DNA MasterPLUSSYBR Green I kits (Roche Diagnostics, Mannheim, Germany) following manufacturer's instructions. The primer sequences for IL-1 $\beta$, ENA-78, and GAPDH used in the study were as follows: IL- $1 \beta$ (sense 5'- CTC CGG GAC TCA CAG CAA AAA -3'), IL-1 $\beta$ (antisense 5'- 
GGG GAA CTG GGC AGA CTC A3'), ENA-78 (sense 5'- TGT TGG TGC TGC TGC TG-3'), ENA-78 (antisense 5'- ACA AAT TTC CTT CCC GTT CTT-3'), GAPDH (sense 5'- GGT GAA GTT CGG AGT CAA CGG A-3'), GAPDH (antisense 5'GAG GGA TCT CGC TCC TGG AAG A-3'). The optimal conditions for PCR amplification were: an initial incubation at $95{ }^{\circ} \mathrm{C}$ for 10 minutes, 45 cycles of denaturation at $95^{\circ} \mathrm{C}$ for 15 seconds, annealing at $55^{\circ} \mathrm{C}$ for 20 seconds, and extension at $72^{\circ} \mathrm{C}$ for 20 seconds. The values of the target gene under investigation and the value of the house-keeping gene (GAPDH) were calculated for each sample using a standard curve.

Estimation of MPO and SOD activity as well as PCO content in intestinal tissue homogenate: Intestinal specimens were weighed and homogenized in 10 volumes phosphate buffer saline $50 \mathrm{mM}, \mathrm{pH} 7$. The crude homogenate was centrifuged in a cooling centrifuge at $7700 \mathrm{x} \mathrm{g}$ for 30 minutes at $4^{\circ} \mathrm{C}$, and the resultant supernatant (free of insoluble materials), was assayed for protein content ${ }^{(22)}$, MPO ${ }^{(23,24)}$, SOD activity ${ }^{(25)}$ and PCO content ${ }^{(26)}$..

Measurement of the tissue VIP assay by ELISA technique: Intestinal tissues were rinsed in ice-cold PBS (0.02 mol/l, $\mathrm{pH} 7.0-7.2)$ to remove excess blood thoroughly and weighed before homogenization. The tissues were minced to small pieces and homogenized in 5-10 $\mathrm{ml}$ of PBS with a glass homogenizer on ice. The resulting suspension was subjected to two freeze-thaw cycles to further break the cell membranes. After that, the homogenates were centrifuged for
5 minutes at $5000 \times \mathrm{g}$. Remove The supernatant was removed, aliquoted and store at $-20^{\circ} \mathrm{C}$.till assayed for VIP using commercial kit supplied by USCN Life Science Inc, USA, ${ }^{(27)}$.

\section{Statistical Analysis:}

Quantitative values of the measured parameters were expressed as mean \pm standard deviation (S.D.). Efficacy $(\%)=100 \times$ (mean number recovered in controls- mean number recovered in treated mice)/ mean number recovered in controls. The data were analyzed by One WayANOVA to detect significance in between groups using Statistical Package for Social Sciences (SPSS), version 14.0 for windows. The difference was considered statistically significant when $\mathrm{P}<0.05$.

\section{RESULTS}

T. spiralis adult count in the small intestine (mean \pm SD): The highest count was recorded in subgroup Ia where mean value of total adult count/ mouse was (110 \pm 2.74$)$. On the other hand the least count was that of subgroup IIb with mean value of adult count/ mouse (5.8 \pm 1.48$)$. Differences between all the subgroups infected by treated larvae and their time corresponding non-treated ones (subgroups IIa and IIIa vs Ia and subgroups IIb and IIIb vs Ib) were found to be statistically highly significant $(P$ values were $<0.001$ for each). Comparison between the two groups infected by treated larvae (groups II and III) revealed statistically significant differences in both scarification times. It is to be mentioned that the highest percentage reduction of the adult count was 
recorded in subgroup IIa $(89.1 \%)$, whereas subgroup IIIb showed the lowest percentage reduction $(73.7 \%)$

(Table 1).

Table 1. T. spiralis adult count (Mean \pm S.D.) in small intestine in the infected groups 5 and 12 d.p.i.

\begin{tabular}{|c|c|c|c|c|c|c|}
\hline Groups & $\begin{array}{l}\text { Group I } \\
\text { non- trea }\end{array}$ & $\begin{array}{l}\text { fected by } \\
\text { d larvae) }\end{array}$ & $\begin{array}{l}\text { Group II } \\
\text { ivermecti } \\
\text { larvae } 5 \mathrm{~d}\end{array}$ & $\begin{array}{l}\text { fected by } \\
\text { reated } \\
\text { i.) }\end{array}$ & $\begin{array}{l}\text { Group II } \\
\text { ivermecti } \\
\text { larvae } 10\end{array}$ & $\begin{array}{l}\text { nfected by } \\
\text { reated } \\
\text { p.i.) }\end{array}$ \\
\hline $\begin{array}{l}\text { Subgroups \& } \\
\text { scarification } \\
\text { times }\end{array}$ & $\begin{array}{l}\text { Ia } \\
\text { 5d.p.i. } \\
(\mathrm{n}=15)\end{array}$ & $\begin{array}{l}\text { Ib } \\
12 \text { d.p.i. } \\
(\mathrm{n}=15)\end{array}$ & $\begin{array}{l}\text { IIa } \\
\text { 5d.p.i. } \\
(n=15)\end{array}$ & $\begin{array}{l}\text { IIb } \\
\text { 12d.p.i. } \\
(\mathrm{n}=15)\end{array}$ & $\begin{array}{l}\text { IIIa } \\
\text { 5d.p.i. } \\
(\mathrm{n}=15)\end{array}$ & $\begin{array}{l}\text { IIIb } \\
\text { 12d.p.i. } \\
(\mathrm{n}=15)\end{array}$ \\
\hline $\begin{array}{l}\text { Adult count/ } \\
\text { mouse }\end{array}$ & $110 \pm 2.74$ & $41.8 \pm 2.39$ & $12 \pm 2.12$ & $5.8 \pm 1.48$ & $\begin{array}{l}19.6 \pm \\
1.14 \\
\end{array}$ & $11 \pm 2.12$ \\
\hline$P_{1}$ & & & $<0.001 * *$ & $<0.001 * *$ & $<0.001 * *$ & $<0.001 * *$ \\
\hline $\boldsymbol{P}_{2}$ & & & & & $<0.001 * *$ & $<0.05^{*}$ \\
\hline$\%$ reduction & & & 89.1 & 86.1 & 82.2 & 73.7 \\
\hline
\end{tabular}

$P$ value $<0.05$ means that difference is statistically significant*.

$P$ value $<0.001$ means that difference is statistically highly significant**.

$P_{I}$ : comparison between subgroups II and subgroups III vs. their corresponding subgroups I.

$P_{2}$ : comparison between subgroups II vs. their corresponding subgroups III.

T. spiralis encysted larval count in the muscles (mean $\pm S D)$ : The mean number of total larvae/ mouse recorded its highest levels in subgroup Ic $(23992 \pm 712.86)$, on the other hand the lowest mean larval count was that of subgroup IIc $(1068 \pm 164.07)$. Comparing the two groups infected by treated larvae with each other and with their corresponding groups infected by non-treated larvae, revealed statistically highly significant differences ( $P$ values were <0.001). As regards to the percentage of total larval count reduction, group II was superior to group III, where mean values were $95.5 \%$ and $77.3 \%$, respectively (Table 2).

Table 2. T. spiralis total larval count (Mean \pm S.D.) in muscles of the infected groups 35 d.p.i.

\begin{tabular}{|l|l|l|l|}
\hline $\begin{array}{l}\text { Group III (infected } \\
\text { by ivermectin treated } \\
\text { larvae 10 d.p.i.) }\end{array}$ & $\begin{array}{l}\text { Group II (infected } \\
\text { by ivermectin } \\
\text { treated larvae 5 d.p.i.) }\end{array}$ & $\begin{array}{l}\text { Group I: (infected } \\
\text { by non- treated } \\
\text { larvae) }\end{array}$ & Groups \\
\hline $\begin{array}{l}\text { IIIc } \\
35 \text { d.p.i. },(\mathrm{n}=15)\end{array}$ & $\begin{array}{l}\text { IIc } \\
35 \mathrm{~d} . \mathrm{p} . \mathrm{i} .,(\mathrm{n}=15)\end{array}$ & $\begin{array}{l}\text { Ic } \\
35 \mathrm{~d} . \mathrm{p} .1 .,(\mathrm{n}=15)\end{array}$ & Subgroups \\
\hline $5452 \pm 292.87$ & $1068 \pm 164.07$ & $23992 \pm 712.86$ & $\begin{array}{l}\text { Adult count/ } \\
\text { mouse }\end{array}$ \\
\hline$<0.001^{* *}$ & $<0.001^{* *}$ & & $\mathbf{P 1}$ \\
\hline$<0.001^{* *}$ & & & $\mathbf{P 2}$ \\
\hline 77.3 & 95.5 & & $\mathbf{\%}$ reduction \\
\hline
\end{tabular}


Levels of $\quad I L-1 \beta \quad m R N A$ expression in intestinal tissue (mean土 SD): Infection with $T$. spiralis (group I), caused a statistically highly significant increase in the mRNA expression of IL- $1 \beta$ at 5 d.p.i. (0.583 \pm 0.24$)$ and at 12 d.p.i. $(0.443 \pm 0.19)$ in comparison to the control non-infected mice (group IV) $(0.201 \pm 0.14)$ where $P$ values were $<0.001$ for each. The same findings were present in group III $(0.376 \pm 0.20$ and $0.373 \pm 0.16)$ at 5 and 12 d.p.i., respectively. On the other hand, in group II, mRNA expression of IL-1 $\beta$ represented the lowest values of all infected groups $(0.243 \pm 0.14$ and
$0.208 \pm 0.10)$ at 5 and 12 d.p.i., respectively, yet its increase was statistically significant when compared to non-infected mice (group IV), where $P$ values were $<0.05$. All the infected groups (I, II and III) showed non- significant increase in the expression of IL-1 $\beta(0.318 \pm 0.18$, $0.210 \pm 0.16$ and $0.314 \pm 0.18$ ), respectively, in comparison to the non-infected group at 35 d.p.i.. It is to be mentioned that differences in the levels of IL-1 $\beta$ mRNA expression between groups II and III, were statistically significant at 5 and 12 d.p.i. (Fig. 1).

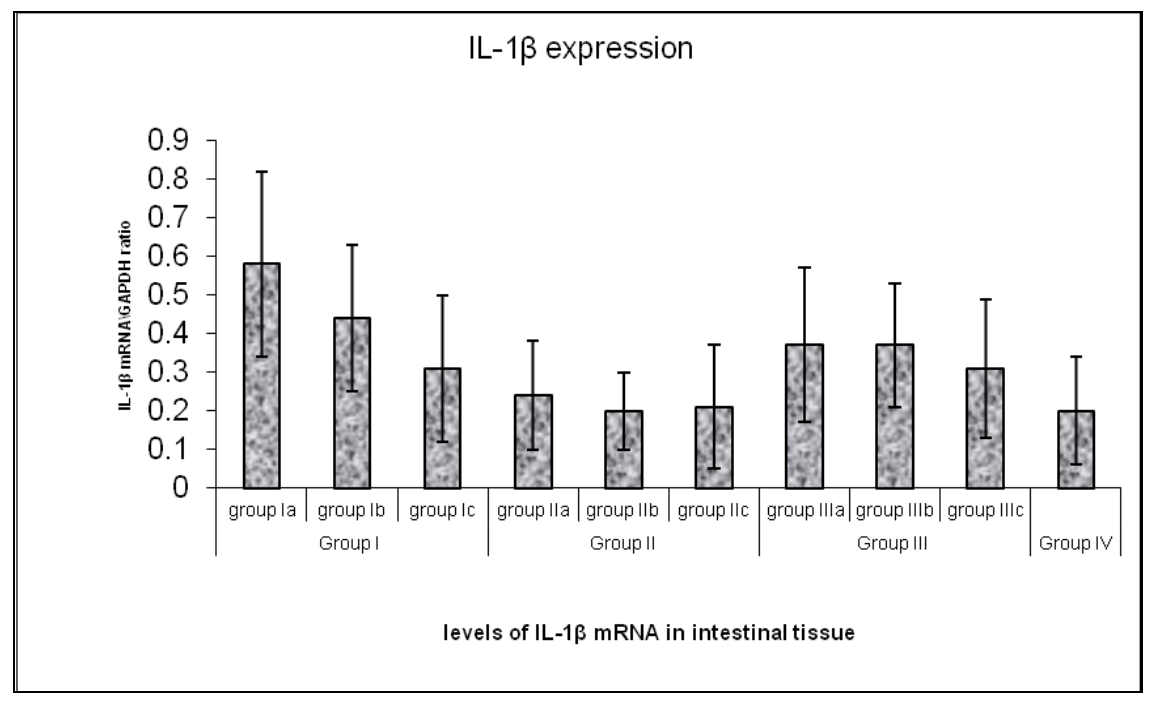

Figure 1. mRNA expression (Mean \pm S.D.) of IL-1 $\beta$ in the intestinal tissue of all studied groups 5, 12 and 35 days post infection d.p.i.

Levels of ENA-78 mRNA expression in intestinal tissue (mean士 SD): Comparison between group Ia, b and c $(0.574 \pm 0.22,0.329 \pm$ 0.18 and $0.072 \pm 0.02$ ), respectively and the non-infected control group (group IV) $(0.011 \pm 0.008)$, revealed highly significant increase in the mRNA expression of ENA-78 where $P$ values were $<0.001$ in all scarification times. In both groups II and III, the differences in the mRNA 
expression of this parameter were statistically highly significant in the $1^{\text {st }}$ scarification time only $(0.531 \pm$ 0.20 and $0.551 \pm 0.29)$, respectively, in comparison to group IV, where $P$ values were $<0.001$. The expressions were then reduced with subsequent significant differences in the $2^{\text {nd }}$ $(0.322 \pm 0.16$ and $0.386 \pm 0.27)$, respectively and $3^{\text {rd }}$ scarification times $(0.039 \pm 0.01$ and $0.052 \pm 0.02)$, respectively where $P$ values were $<0.05$. Statistical significant differences in the mRNA expression of ENA-78 were documented during the whole study when comparing both groups II and III with group I. Moreover, differences in the levels of ENA-78 mRNA expression between groups II and III, were statistically significant throughout the whole work (5, 12 and 35 d.p.i.) (Fig. 2).

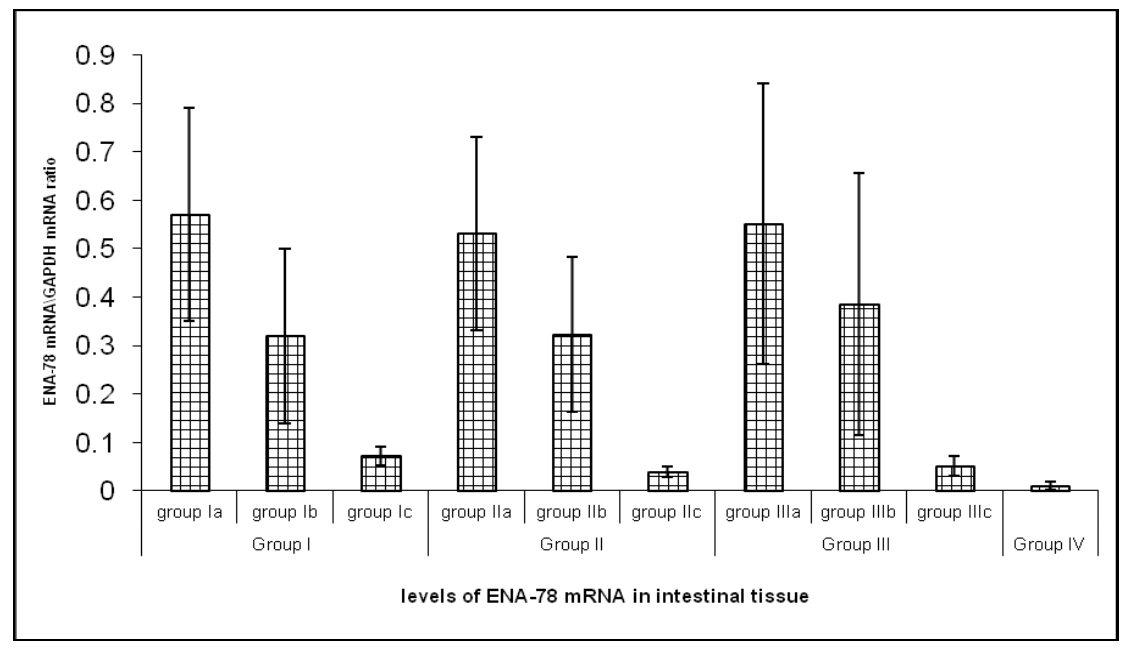

Figure 2. mRNA expression (Mean \pm S.D.) of ENA-78 in the intestinal tissue of all studied groups 5, 12 and 35 days post infection d.p.i.

Levels of VIP and PCO as well as MPO and SOD activity in the intestinal tissue homogenate (mean \pm $S D)$ : As regards VIP and PCO levels as well as MPO activity, there was a statistically significant increase in group 1 (infected non-treated mice) compared to control group (group IV) as well as infected treated groups (group II and III) at 5 and 12 d.p.i. $(P<0.05)$. Meanwhile, VIP and PCO levels as well as MPO activity significantly reduced in group II compared to group III at 5 and 12 d.p.i. $(P<0.05)$. For SOD activity there was a significant increase in its activity in group I and group III in comparison with each of group II and group IV at 5, 12 d.p.i. $(P<0.05)$. Moreover, at 35 d.p.i., all the studied biochemical parameters showed no significant difference between all infected groups in comparison to group IV (Table 3 and 4). 
Bull. Egypt. Soc. Physiol. Sci. 33 (2) 2013

Soliman et al.

Table 3. Levels of VIP and PCO in the intestinal homogenates of all studied groups 5, 12 and 35 d.p.i.

\begin{tabular}{|c|c|c|c|c|c|c|c|c|c|c|c|}
\hline \multirow{2}{*}{\multicolumn{2}{|c|}{$\begin{array}{l}\text { Groups/ } \\
\text { Parameters }\end{array}$}} & \multicolumn{3}{|c|}{$\begin{array}{l}\text { Group I (infected by non- treated } \\
\text { larvae) }\end{array}$} & \multicolumn{3}{|c|}{$\begin{array}{l}\text { Group II (infected by ivermectin } \\
\text { treated larvae } 5 \text { d.p.i.) }\end{array}$} & \multicolumn{3}{|c|}{$\begin{array}{l}\text { Group III (infected by ivermectin } \\
\text { treated larvae } 10 \text { d.p.i.) }\end{array}$} & \multirow{2}{*}{$\begin{array}{l}\text { Group IV } \\
\text { (non- } \\
\text { infected } \\
\text { mice) }\end{array}$} \\
\hline & & Ia & Ib & Ic & IIa & IIb & IIc & IIIa & IIIb & IIIc & \\
\hline \multirow{7}{*}{$\begin{array}{l}\text { VIP level } \\
\text { (pmol/mg } \\
\text { protein) }\end{array}$} & $\begin{array}{l}\text { Mean } \pm \\
\text { S.D. }\end{array}$ & $3.1 \pm 0.91$ & $2.9 \pm 0.45$ & $2.5 \pm 0.88$ & $2.7 \pm 0.75$ & $2.3 \pm 0.75$ & $2.1 \pm 0.62$ & $2.8 \pm 0.84$ & $2.65 \pm 0.71$ & $2.2 \pm 0.53$ & $2 \pm 0.42$ \\
\hline & $P_{1}$ & $<0.05^{*}$ & $<0.05^{*}$ & $\mathrm{NS}$ & $<0.05^{*}$ & $<0.05^{*}$ & $\mathrm{NS}$ & $<0.05^{*}$ & $<0.05^{*}$ & NS & \\
\hline & $t_{1}$ & 3.660 & 3.110 & 2.003 & 2.600 & 1.996 & 1.522 & 1.886 & 2.413 & 1.104 & \\
\hline & $P_{2}$ & & & & $<0.05 *$ & $<0.05^{*}$ & $\mathrm{NS}$ & $<0.05^{*}$ & $<0.05^{*}$ & $\mathrm{NS}$ & \\
\hline & $t_{2}$ & & & & 2.658 & 4.325 & 1.441 & 3.252 & 2.692 & 1.263 & \\
\hline & $P_{3}$ & & & & & & & $<0.05^{*}$ & $<0.05^{*}$ & NS & \\
\hline & $t_{3}$ & & & & & & & 4.159 & 3.225 & 1.444 & \\
\hline \multirow{7}{*}{$\begin{array}{l}\text { PCO } \\
\text { level } \\
\text { (nmol/mg } \\
\text { protein) }\end{array}$} & $\begin{array}{l}\text { Mean } \pm \\
\text { S.D. }\end{array}$ & $15.3 \pm 3.61$ & $14.1 \pm 2.41$ & $12.1 \pm 2.74$ & $13.5 \pm 3.88$ & $12.65 \pm 4.62$ & $11.5 \pm 1.55$ & $13.93 \pm 3.11$ & $13.1 \pm 2.97$ & $11.92 \pm 42.20$ & $10.9 \pm 2.58$ \\
\hline & $P_{1}$ & $<0.05^{*}$ & $<0.05^{*}$ & $\mathrm{NS}$ & $<0.05^{*}$ & $<0.05^{*}$ & $\mathrm{NS}$ & $<0.05^{*}$ & $<0.05^{*}$ & NS & \\
\hline & $t_{1}$ & 2.996 & 3.110 & 1.528 & 2.253 & 2.996 & 0.352 & 1.998 & 2.996 & 0.796 & \\
\hline & $P_{2}$ & & & & $<0.05^{*}$ & $<0.05^{*}$ & NS & $<0.05^{*}$ & $<0.05 *$ & NS & \\
\hline & $t_{2}$ & & & & 2.152 & 2.536 & 0.854 & 2.225 & 2.158 & 0.635 & \\
\hline & $P_{3}$ & & & & & & & $<0.05^{*}$ & $<0.05^{*}$ & NS & \\
\hline & $t_{3}$ & & & & & & & 2.320 & 2.358 & 0.685 & \\
\hline
\end{tabular}

$P$ value $<0.05$ means that difference is statistically significant ${ }^{*} \quad$ NS means not significant

$P 1$ comparing subgroups I, II and III Vs group IV. P2 comparing subgroups II and III Vs their corresponding subgroups I.

P3 comparing subgroups II Vs their corresponding subgroups III. 
Bull. Egypt. Soc. Physiol. Sci. 33 (2) 2013

Soliman et al.

Table 4. Activity of MPO and SOD in the intestinal homogenates of all the studied groups 5 , 12 and 35 d.p.i.

\begin{tabular}{|c|c|c|c|c|c|c|c|c|c|c|c|}
\hline \multirow{2}{*}{\multicolumn{2}{|c|}{$\begin{array}{l}\text { Groups/ } \\
\text { Parameters }\end{array}$}} & \multicolumn{3}{|l|}{ Group I } & \multicolumn{3}{|c|}{ Group II } & \multicolumn{3}{|c|}{ Group III } & \multirow[t]{2}{*}{$\begin{array}{l}\text { Group IV } \\
\text { (non-infected } \\
\text { mice) }\end{array}$} \\
\hline & & $\begin{array}{l}\text { Ia } \\
5 \text { d.p.i. }\end{array}$ & $\begin{array}{l}\text { Ib } \\
12 \text { d.p.i. }\end{array}$ & $\begin{array}{l}\text { Ic } \\
35 \text { d.p.i. }\end{array}$ & $\begin{array}{l}\text { IIa } \\
5 \text { d.p.i. }\end{array}$ & $\begin{array}{l}\text { IIb } \\
12 \text { d.p.i. }\end{array}$ & $\begin{array}{l}\text { IIc } \\
35 \text { d.p.i. }\end{array}$ & $\begin{array}{l}\text { IIIa } \\
5 \text { d.p.i. }\end{array}$ & $\begin{array}{l}\text { IIIb } \\
12 \text { d.p.i. }\end{array}$ & $\begin{array}{l}\text { IIIc } \\
35 \text { d.p.i. }\end{array}$ & \\
\hline \multirow{7}{*}{$\begin{array}{l}\text { MPO } \\
\text { activity } \\
\text { (ng/mg } \\
\text { protein) }\end{array}$} & $\begin{array}{l}\text { Mean } \pm \\
\text { S.D. }\end{array}$ & $1.90 \pm 0.46$ & $1.69 \pm 0.36$ & $1.23 \pm 0.52$ & $1.5 \pm 0.51$ & $1.3 \pm 0.35$ & $1 \pm 0.42$ & $1.7 \pm 0.36$ & $1.54 \pm 0.58$ & $1.15 \pm 0.41$ & $0.9 \pm 0.07$ \\
\hline & $P_{1}$ & $<0.05^{*}$ & $<0.05^{*}$ & $\mathrm{NS}$ & $<0.05 *$ & $<0.038^{*}$ & NS & $<0.05^{*}$ & $<0.05^{*}$ & NS & \\
\hline & $t_{1}$ & 2.811 & 3.100 & 10225 & 4.318 & 2.117 & 1.449 & 2.463 & 3.240 & 1.220 & \\
\hline & $P_{2}$ & & & & $<0.05^{*}$ & $<0.05^{*}$ & $\mathrm{NS}$ & $<0.05^{*}$ & $<0.05^{*}$ & $\mathrm{NS}$ & \\
\hline & $t_{2}$ & & & & 1.859 & 2.663 & 2.110 & 2.014 & 3.201 & 1.225 & \\
\hline & $P_{3}$ & & & & & & & $<0.05^{*}$ & $<0.05^{*}$ & $\mathrm{NS}$ & \\
\hline & $t_{3}$ & & & & & & & 1.889 & 2.528 & 1.741 & \\
\hline \multirow[t]{7}{*}{$\begin{array}{l}\text { SOD } \\
\text { activity } \\
\text { (U/mg } \\
\text { protein) }\end{array}$} & $\begin{array}{l}\text { Mean士 } \\
\text { S.D. }\end{array}$ & $2.7 \pm 0.60$ & $2.92 \pm 0.58$ & $2.3 \pm 0.32$ & $2.4 \pm 0.41$ & $2.64 \pm 0.85$ & $1.99 \pm 0.62$ & $2.5 \pm 0.47$ & $2.81 \pm 0.68$ & $2.1 \pm 0.47$ & $1.95 \pm 0.93$ \\
\hline & $P_{1}$ & $<0.001^{* *}$ & $<0.05 *$ & NS & $<0.05 *$ & $<0.05^{*}$ & $\mathrm{NS}$ & $<0.05 *$ & $<0.05^{*}$ & NS & \\
\hline & $t_{1}$ & 5.418 & 4.253 & 1.332 & 4.250 & 3.260 & 1.885 & 4.152 & 3.212 & 1.159 & \\
\hline & $P_{2}$ & & & & $<0.05 *$ & $<0.05^{*}$ & $\mathrm{NS}$ & $\mathrm{NS}$ & NS & NS & \\
\hline & $t_{2}$ & & & & 2.140 & 2.623 & 0.472 & 0.765 & 0.355 & 0.332 & \\
\hline & $P_{3}$ & & & & & & & $<0.05^{*}$ & $<0.05^{*}$ & $\mathrm{NS}$ & \\
\hline & $t_{3}$ & & & & & & & 2.418 & 2.581 & 0.783 & \\
\hline
\end{tabular}

$P$ value $<0.05$ means that difference is statistically significant*

NS means not significant

P1 comparing subgroups I, II and III Vs group IV. P2 comparing subgroups II and III Vs their corresponding subgroups I.

P3 comparing subgroups II Vs their corresponding subgroups III. 


\section{DISCUSSION}

Trichinellosis is a disease that not only represents a public health hazard by affecting human but also causes an economic problem in porcine animal production. It is responsible for reemerging zoonoses threatening millions of people all over the world $^{(\mathbf{2 8 , 2 9})}$. Moreover, the effects of globalization exacerbate the risk of spreading trichinellosis which may be related mainly to a reduced efficacy of the veterinary control on susceptible animals. This represents a serious problem for the meat trade ${ }^{(30)}$. Therefore, the main efforts in many countries have focused on the control or elimination of Trichinella from the food chain ${ }^{(31)}$. The need for effective compounds for the prevention and treatment of trichinellosis in humans and animals has led to the testing of several drugs which are clinically effective against other nematodes ${ }^{(5)}$.

The present work has studied the effect of in vivo exposure of $T$. spiralis newborn and migrating larvae to IVM on their subsequent invasive power and their ability to establish a new infection in experimental animals.

IVM is a drug which elicits a potent and persistent paralysis of nematode musculature ${ }^{(32)}$. IVM primarily targets cys-loop receptors called GluCls ${ }^{(33)}$ and possibly GABA receptors as a secondary target ${ }^{(\mathbf{3 4})}$. IVM is believed to act on susceptible nematodes by potentiating the release and binding of GABA in certain nerve synapses, and thus blocking GABA-mediated transmission of nerve signals. While paralysis is the most evident effect, suppression of reproductive processes has been observed. IVM is active against immature as well as mature worms ${ }^{(35)}$.

In the early intestinal stage of infection with $T$. spiralis, there are alterations in expression of proinflammatory cytokines and chemical code of enteric neurons as well as the antioxidant capacity of the small intestine ${ }^{(36)}$. Thus, the present study was designed to characterize the changes in the expression pattern of IL-1 $\beta$ and ENA-78 and estimation of VIP level and MPO as well as SOD activities and PCO content in tissue homogenate of the small intestines of mice.

During the intestinal phase of infection, $T$. spiralis adults localize to the crypt-villus junction, establishing an intra-multicellular niche. The parasites migrate in the epithelium, continually invading and occupying the cytoplasm of new epithelial cells, and do not appear to cross the basement membrane. The invasion of host intestinal epithelium by the infective larvae is the first step during T. spiralis infections ${ }^{(37)}$. Parasite invasion relies on determined characteristics of the enterocytes and the parasite must receive chemical signals from the cells to initiate the invasive process $^{(38)}$. T. spiralis appears to secrete excretory-secretory proteins, e.g. serine proteases, cysteine proteases, and metalloproteases, during penetration of the intestinal mucosa in order to invade the columnar epithelial cells and to induce fusion of the cell membranes, which gives rise to the formation of the syncitium in which the larvae live and molt ${ }^{(39)}$. 
Mucosal inflammatory response appears through the release of proinflammatory cytokines and inflammatory mediators. However, the patterns of epithelial cytokine response vary with the site of infection and type of pathogen ${ }^{(40)}$. It is noteworthy that the cytokines released from the intestinal epithelial cells (IEC) with their subsequent inflammatory infiltrates were implicated in exacerbating the underlying disease ${ }^{(\mathbf{4 1})}$. IEC respond to the $T$. spiralis infection with early and transient release of proinflammatory cytokines as IL-1 $\beta$ and ENA-78 ${ }^{(\mathbf{4 2})}$.

In the present work, there was a significant increase in mRNA expression of IL-1 $\beta$ and ENA-78 in group of mice infected by non-treated larvae (group I) more than that in groups infected by treated larvae; group II (infected by larvae treated 5 d.p.i.) and group III (infected by larvae treated 10 d.p.i.) as compared to negative control group (group IV). These parameters showed a significant reduction in their expression under the effect of ivermectin in group II more than group III at both 5 and 12 d.p.i.. As regard to IL-1 $\beta$ mRNA expression at $35^{\text {th }}$ d.p.i., there was no significant difference between all studied groups, unlike ENA-78 mRNA expression where there was a significant difference between all studied groups. These results could be explained by the findings of Yang et al. ${ }^{(43)}$ and Stadnyk and waterhouse ${ }^{(44)}$. They reported that ENA-78 expression was long lasting but delayed in onset while IL- $1 \beta$ is known to attract and activate macrophages, NK cells, and T and $\mathrm{B}$ cells and has been found in primary epithelial cells from rats even after 2 days of infection with $T$. spiralis. Therefore, up-regulation of these proinflammatory cytokines may contribute to the initiation of acute inflammatory responses ${ }^{(6)}$.

Our study indicated that the inflammatory changes decreased in the group of mice infected with IVM treated larvae on the $5^{\text {th }}$ more than the $10^{\text {th }}$ d.p.i.. This correlation between IL-1 $\beta$ and inflammatory changes was clearly stated by Stadnyk and waterhouse $^{(44)}$. They proved that IL$1 \beta$ increased during the time of infection when the greatest cellular and pathological changes are occurring in the $T$. spirals infected gut. Recently, an experimental model of intestinal $T$. spiralis infection documented high levels of intestinal IL-1 $\beta$ mRNA expression in lamina propria- associated inflammatory cells compared to the non- infected mice $^{(45)}$. Moreover, Despommier ${ }^{(46)}$ reported that IL-1 $\beta$ may serve directly as a neutrophil chemoattractant or facilitate leukocyte emigration by inducing adhesion molecule expression on endothelial cells and stimulating chemokine production for example ENA-78. Therefore, IL-1 $\beta$ was proved to be a crucial mediator in the establishment of the inflammatory reactions in response to infection ${ }^{(47)}$. In the same context, Jackson et al. ${ }^{(\mathbf{4 8})}$ reported that IEC are sources of cytokines in various gastrointestinal inflammatory conditions, including infections and inflammatory bowel diseases, in which neutrophil infiltrates are implicated in exacerbating the underlying disease. Shen et al. ${ }^{(49)}$ reported that neutrophil migration into the $T$. spiralis-infected rodent intestine has been examined by 
increased expression of epithelial neutrophil activated peptide and increased transcriptional activation of ENA-78.

Li et al. ${ }^{(6)}$ demonstrated that invasion by $T$. spiralis caused an elevation of mRNA of IL-1 $\beta$ and ENA-78 in the IEC. The observed increase was dose dependent. Levels of IL-1 $\beta$ and ENA-78 were increased even when 1000 larvae were used, but much greater increases were observed when 5000 larvae were used. So, our results confirm that finding and reflect the effect of attenuating larvae by IVM in reduction of IL- $1 \beta$ and ENA78 mRNA expressions.

Concerning the VIP in the small intestine, it exhibits a broad significance in intestinal physiology. Functionally, VIP was originally identified in the gastrointestinal tract and named for its potent vasodilator actions. It is also known to govern regulation of motility, inhibit the peristaltic reflex in the circular smooth muscle layer, control intestinal blood flow, and modulate the immune system. VIP is released from nerve terminals with enzymes of the nitric oxide (NO) synthesis cascade in the myenteric plexus and, together, these peptides are believed to be the primary components of nonadrenergic and noncholinergic nerve transmission in the gut. Several types of immune cells, including $\mathrm{T}$ lymphocytes may function as local VIP sources in the lymphoid microenvironment ${ }^{(\mathbf{1 3 , 5 0 )}}$.

Our results showed significant increase of VIP level in all infected groups in comparison to non-infected group at both 5 and 12 d.p.i.. There was a significant reduction in its level under the effect of IVM treatment in group II more than group III at both 5 and 12 d.p.i.. At 35 d.p.i., there was no significant difference between all infected groups which reflect an understanding of the putative changes in the innervation pattern of the intestine in long-lasting trichinellosis when infection has progressed to the muscle phase and adult worms found in the intestine is limited ${ }^{(51)}$. Inflammation of the bowel leads to release of proinflammatory mediators, which act on the enteric nervous system (ENS) resulting in activation of enteric neurons, suppression of neurotransmitter release, and altered receptor expression ${ }^{(52)}$. Palmer and Koch $^{(53)}$ indicated that activation of enteric neurons is an important component of an intricate defense process against $T$. spiralis in the gastrointestinal tract lumen.

Furness ${ }^{(54)}$ stated that the ENS regulates and coordinates almost all aspects of intestinal function including gut motility, the transport of fluid and electrolytes, the secretion of mucin, the production of cytokines, and the regulation of epithelial barrier function. Also, Ganea ${ }^{(58)} \mathbf{1 9 9 6}$ reported that cytokine neuroendocrine network have a significant impact on cytokine production and function. Therefore, the immunomodulatory activities of VIP could be mediated, at least partially, through effects on the production of cytokines as IL-1 $\beta$ and ENA-78.

Infections with $T$. spiralis stimulate proliferation of mast cells ${ }^{(56)}$ and the necrotic epithelial cells release a key danger signal capable of activating mast cells ${ }^{(57)}$. Wood ${ }^{(58)}$ showed that several mast cell-derived 
mediators have neuropharmacological actions on the electrical and synaptic behavior of neurons in the ENS including histamine, IL-6, and platelet activating factor, mast cell proteases, IL-1 $\beta$, and prostaglandins. This coincides with our results that both proinfammatory cytokines and VIP control the level of each other by indirect mechanisms. Pozo and Delgado $^{(59)}$ reported that VIP in the jejunum during the early enteric phase of $T$. spiralis-infection undergoes upregulation., Therefore, it is possible that regulation of VIP in the jejunum is a long term effect and this confirm our results as the level of VIP became nearly normal at day 35 post infection in all infected groups.

Myeloperoxidase (MPO) is a lysosomal protein secreted by white blood cells. It is used as a biochemical index of neutrophil infiltration to assess intestinal inflammation because there is a close correlation between the increase in MPO activity and the extent of mucosal damage in the jejunum ${ }^{(60)}$. Our results showed significant increase in MPO activity in all infected groups in comparison to noninfected group at both 5 and 12 d.p.i. There was a significant reduction of its activity in group II more than group III at 5,12 d.p.i. At $35^{\text {th }}$ d.p.i., there was no significant difference between all infected groups that again reflect the role of IVM in attenuation of larvae and reduction of its inflammatory effect on intestinal mucosa.

Derda et al. ${ }^{(61)}$ and Stadnyk et al. ${ }^{(42)}$ stated that neutrophil migration parallels the cytokine expression by IEC and that cytokine levels are diminished when neutrophils are prevented from reaching the epithelium. Thus proinflammatory cytokine production is directly proportion to MPO activity in inflammatory conditions as nematode infection. They reported that $T$. spiralis-infected rodent intestine showed increase of neutrophil migration with significantly increased MPO in gut samples. So the reduced MPO activity in IVM-treated groups indicates the decrease in magnitude of intestinal inflammation and neutrophil infiltration especially in group II (Histopathological data not shown).

Bercik et al. ${ }^{(62)}$ reported that the activity of MPO in the jejunums of $T$. spiralis-infected mice was increased on the 7 d.p.i., remained elevated on days 14 and 21, and normalized after 28 d.p.i. The observed changes correspond to the infiltration of neutrophils and esinophils that run hand in hand with our results as MPO activity was normalized by 35 d.p.i. in all infected groups.

Oxidative stress arises when there is a marked imbalance between the production of ROS and their removal by antioxidants. In reaction to mild oxidative stress, tissues often respond by producing more antioxidants; however, severe persistent oxidative stress depletes body antioxidant resources and overtakes its ability to produce more antioxidants, leading to lower antioxidant levels and injury in the tissues ${ }^{(63)}$. ROS may seriously damage all types of biological molecules, including proteins, lipids, or DNA. However, proteins are possibly the most immediate vehicle for inflicting oxidative damage on cells. Carbonylated proteins tend to 
form high-molecular-weight aggregates that are resistant to degradation and accumulate as damaged proteins ${ }^{(\mathbf{6 4})}$. Detection of increased level of PCO has proposed as a sign of disease associated dysfunction ${ }^{(65)}$.

During trichinellosis, pathological changes in various tissues, including the epithelium of the small intestine and the skeletal muscles, are observed. It is possible that this tissue damage is mediated by free radicals, generated both by the host and by the parasite ${ }^{(66)}$. Therefore, the present study was undertaken to examine the changes in the activity of the antioxidant enzymes SOD as well as PCO content as a part of the biochemical defense mechanisms of the host during trichinellosis.

As regard to SOD activity in intestinal tissue homogenate, there was a significant increase in its activity in group I and group III in comparison with each of group II and group IV at 5 and $12^{\text {th }}$ d.p.i. This reflects the importance of the early treatment of larvae by ivermectin to minimize the severity of oxidative stress reaction. Both SOD activity and PCO level return quiet nearly normal as there was no significant difference between infected and non-infected groups at day 35 d.p.i.

To our knowledge, there is no study which evaluates the antioxidant status as regard to SOD activity and PCO content in intestinal tissue of $T$. spiralis infected mice under the effect of IVM. However, our results showed no significant difference between group I and III as regard to SOD activity. So, they are considered as weak biomarkers for follow up of the efficacy of IVM and the power of invasion of treated larvae. This may be due to the fact reported by Derda et $\mathbf{a l}^{\left({ }^{(66)}\right.}$ that the generation of oxygenderived free radicals may be an initial, nonspecific defense reaction of the host toward parasitic infection.

The efficacy of IVM in reducing the infectivity of $T$. spiralis larvae was estimated by $T$. spiralis adult and its effect on the fecundity was assessed by larval counts and their percentages of reduction. It was found that the least adult count was observed in group II at both scarification times with statistically highly significant differences when compared to both group I and group III $(P<0.001$ for each). Also, the highest percentage reduction of the $T$. spiralis adult count was recorded in subgroup IIa (89.1\%). As regard the total larval counts, they were greatly reduced in groups infected with treated larvae with the lowest larval counts in group II with statistically highly significant differences when compared to both group I and group III $(P<0.001$ for each). The highest percentage larval reduction was recorded in group II $(95.5 \%)$. Soliman et al., (7) and ElAzzouni ${ }^{(67)}$ reported that IVM was most effective when administered as early as possible after infection, its effect diminished progressively thereafter and this agreed with our results as $T$. spiralis adults and larval counts as well as inflammatory cytokine expressions were reduced when infection was established using larvae treated by IVM 5 d.p.i., more than those treated 10 d.p.i..

The same findings were found in other nematodes treated by IVM. Fu et al. ${ }^{(68)}$ found that IVM was more 
efficacious for migrating larvae of Baylisascaris transfuga than for encapsulated larvae because encapsulation of the larva may block the infiltration of drug. Similarly, Satou et al. ${ }^{(69)}$ assessed the effect of IVM against Strongyloides larvae. They found that IVM caused an adequate decrease in their viability. This raises the concept that $T$. spiralis larvae in the IVM-treated mice have been adversely affected by treatment with subsequent effect on their infectivity.

In the same context, Klager et

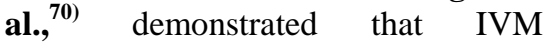
impaired both development and fecundity of adult $O$. volvulus. Similarly, Ottesen et al. ${ }^{\text {(71) }}$ and Yates et al. ${ }^{(72)}$ demonstrated that IVM treatment of filariasis produced an initial dramatic drop in the levels of circulating microfilariae, followed by long-term suppression of their production. Beech et al. ${ }^{(73)}$ reported that another possibility is that IVM disrupts filarial processes that modulate the host immune system. The immunomodulatory ability of filarial nematodes is characterized by suppression of Th1 and Th2 responses, impaired proliferation of $\mathrm{T}$ cells, increased production of the regulatory cytokine IL-10 and suppression of releasing proinflammatory cytokines. Hence, IVM was supposed to be an effective health strategy for filarial control ${ }^{(74)}$.

Satou et al., 2001 ${ }^{(69)}$ stated that the larvae had been weakened to a certain extent with IVM treatment (as in phase 1 of our study). Linking together with the findings of Andronicos et al., (75) should explain our results of decreased inflammation in the intestine with IVM treated larvae. They found that intestinal epithelial cells affected usually as a result of tissue trauma induced by motile $T$. colubriformis larvae but not IVM-paralyzed larvae indicating that the plasma membrane integrity of epithelial cells was compromised by the motility of the parasite. Necrosis of intestinal epithelial cells may be fundamental to initiation of an appropriate host response against gastrointestinal nematodes.

In conclusion, IVM has not only a great role in the treatment of $T$. spiralis infection but also has an impressive effect as a control agent. It appears to affect the subsequent infectivity of $T$. spiralis larvae beside its effect on decreasing the number of $T$. spiralis adults and encysted larvae later on. These effects were more pronounced when IVM was given early in the infection. So, in the absence of a completely effective treatment for trichinellosis, an early chemotherapy using IVM is feasible and useful in the treatment of current infection and control of subsequent infections with $T$. spiralis. Therefore, IVM can help us to achieve a meat production system with a negligible risk for Trichinella and on the long run may eliminate this parasite and reduce the global cost of controlling this infection.

\section{REFERENCES}

1- Sofronic-Milosavljevic Lj, Djordjevic M, Plavsic B, Grgic B (2013): Trichinella infection in Serbia in the first decade of the twenty-first century. Vet. Parasitol., 194(2-4):145-149. 
2- Momoh HA, Bello M, Inabo H, Wada Y, Adole EB, Madaiki BD, Aregbe EA. (2013): Prevalence and some risk factors associated with trichinellosis in backyard pig farms in Zaria, Nigeria. Trop. Anim. Health Prod., 45(5):1149-1152.

3- Feng XP, Hayashi J, Beech RN, Prichard RK. (2002): Study of the nematode putative GABA type-A receptor subunits: evidence for modulation by ivermectin. J. Neurochem., 83(4): 870-878.

4- Shoop WL, Haines HW, Michael BF, Eary CH. (1993): Mutual resistance to avermectins and milbermycins: oral activity of ivermectin and moxidectin against ivermectin-resistance and susceptible nematodes. The Vet. Rec., 133(18): 445- 447.

5- Soliman GA, Taher ES, Mahmoud MA(2011):

Therapeutic efficacy of Dormectin, Ivermectin and Levamisole against different stages of Trichinella spiralis in rats. Turkiye Parazitol. Derg.,, 35(2):86-91.

6- Li CK, Seth R, Gray T, Bayston R, Mahida YR, Wakelin D(1998): Production of proinflammatory cytokines and inflammatory mediators in human intestinal epithelial cells after invasion by Trichinella spiralis. Infect. Immun., 66(5): 22002206.

7- Kelles A, Janssens J, Tack J(2002): Electrical behaviour of interleukin-1 $\beta$ (IL-1 $\beta$ ) and prostaglandin- $\mathrm{E}_{2} \quad\left(\mathrm{PGE}_{2}\right)$ on colonic myenteric neurones.
Journal of neurogastroenterol. Motil., 14(4): 321- 330.

8- Cominelli F, Nast CC, Dinarello CA, Gentilini P, Zipser RD(1989): Regulation of eicosanoid production in rabbit colon by interleukin-1. Gastroenterol., 97(6): 1400-05.

9- Dinarello CA(1996): Biologic basis for IL-1 in disease. Blood 87(6): 2095-2147.

10- Gross KG, Pothoulaki C(2007): Role of neuropeptides in inflammatory bowel disease. Inflammatory Bowel Diseases 13(7): 918-932.

11- Goyal RK, Hirano I (1996): The enteric nervous system. N. Engl. J. Med., 334(17): 1106- 15.

1. 12 Palmer JM, Wong-Riley M, Sharkey KA(1998): Functional alterations in jejunal myenteric neurons during inflammation in nematode-infected guinea pigs. Am. J. Phys. Gastroint.Liver Physiol., 275: 922- 935.

12- Porter AJ, Wattchow DA, Brookes SJ, Costa M (1999): Projections of nitric oxide synthase and vasoactive intestinal polypeptide-reactive submucosal neurons in the human colon. J. Gastroenterol. Hepatol., 14(12): 1180-7.

13- Ou X, Tang L, Mccrossan M, Henkle-Duhrsen K, Selkirk ME (1995): Brugia malayi: Localization and differential expression of extracellular and cytoplasmic $\mathrm{CuZn}$ superoxide dismutases in adults and microfilariae. Experimental Parasitology 80(3): 515529.

14- Muller FL, Song W, Liu Y, Chaudhuri A, Pieke-Dahl S, 
Strong R, Huang TT, Epstein CJ, Roberts $L J 2^{\text {nd }}$, Csete $M$, Faulkner JA, Van Remmen $\mathbf{H}$ (2006): Absence of $\mathrm{CuZn}$ superoxide dismutase leads to elevated oxidative stress and acceleration of age-dependent skeletal muscle atrophy. Free Radic. Biol. Med., 40 (11): 19932004.

15- Dalle-Donne I, Rossi R, Giustarini D, Milzani A(2003): Colombo R Protein carbonyl groups as biomarkers of oxidative stress. Clin. Chim. Acta 329(12):23-38.

16- Cetinkaya A, Bulbuloglu E, Kantarceken B, Ciralik H, Kurutas EB, Buyukbese MA, Gumusalan Y(2006): Effects of L-carnitine on oxidant/antioxidant status in acetic acid-induced colitis. Dig. Dis. Sci., 51(3): 488-94.

17- Gálvez J, Garrido $M$, Merlos M, Torres MI, Zarzuelo A(2000): Intestinal antiinflammatory activity of UR12746, a novel 5-ASA conjugate, on acute and chronic experimental colitis in the rat. Br. J. Pharmacol.,. 130(8):1949-59.

18- Dunn IJ, Wright KA(1985): Cell injury caused by Trichinella spiralis in the mucosal epithelium of B10A mice. J. Parasitol., 71 (6): 757- 66.

19- Vallance BA, Blennerhassett PA, Huizinga JD and Collins SM (2001): Mast cellindependent impairment of host defense and muscle contraction in T. spiralis-infected W/W(V) mice. Am. J. Physiol.
Gastrointest. Liver Physiol., 280(4):640-648.

20- Denham DA(1965): Studies with methyridine and Trichinella spiralis. I. Effect upon the intestinal phase in mice. Exp. Parasitol., 17(1): 10-14.

21- Lowry OH, Rosenbrough NJ, Farr AL, Randall RJ(1951): Protein measurements with the Folin phenol reagent. J.Biol. Chem., 193(1):265- 75.

22- Krawisz JE, Sharon P, Stenson WF(1984): Quantitative assay for acute intestinal inflammation based on myeloperoxidase activity. Assessment of inflammation in rat and hamster models. Gastroenterol., 87(6): 1344-50.

23- Agner K(1963): Studies on Myeloperoxidase Activity. I. Spectrophotometry of the MPO$\mathrm{H} 2 \mathrm{O} 2$ Compound. Acta Chem Scand., 17(Suppl. 1): 332-338

24- Sun Y, Oberley LW, Li Y(1988): A Simple method for clinical assay of superoxide dismutase. Clin. Chem., 34(3): 497-500.

25- Reznick AZ, packer, L(1994): Oxidative damage to proteins. Spectrophotometric method for carbonyl assay. Methods Enzymol., 233:357.

26- Todorovic V, Janic B, Koko V, Micev M, Nikolic JA, Ratkovic M, Leposavic G, Jankovic T, Knezevic-Usaj S, Milicevic Z(1996): Colonic vasoactive intestinal polypeptide (VIP) in ulcerative colitis- a radioimmunoassay and immunohistochemical study. 
Hepatogastroenterol., 43(9):483488.

27- Bruschi F(2012): Trichinellosis in developing countries: is it neglected? J. Infect. Dev. Countries 6(3): 216-222.

28- Papatsiros VG, Boutsini S, Ncousi D, Stougiou D, Mintza D and Bisias A(2012): Detection and zoonotic potential of Trichinella spp. From free- range pig farming in Greece. Foodborne Pathog. Dis., 9(6): 536- 540.

29- Blaga $R$, Durand, B, Antoniu S, Gherman C, Cretu CM, Cozma V, Boireau PA(2007): Dramatic increase in the incidence of human trichinellosis in Romania over the past 25 years: impact of political changes and regional food habits. Am. J. Trop. Med. Hyg., 76:983-6.

30- Pozio E, Rinaldi L, Marucci G, Musella V, Galati F, Cringoli G, Boireau P, La Rosa G(2009):. Hosts and habitats of Trichinella spiralis and Trichinella britovi in Europe. Int. J. Parasitol., ; 39(1):71-9.

31- Atterby H, Learmount J, Conyers C, Zimmer I, Boonham N, Taylor M(2009): Development of a real-time PCR assay for the detection of T. spiralis in situ. Vet. Parasitol., 161(1-2): 92-98.

32- Wolstenholme AJ, Rogers AT(2005): Glutamate-gated chloride channels and the mode of action of the avermectin/milbemycin anthelmintics. Parasitology 131(Auppl.): S85-S96.

33- Beech R, Levitt N, Cambos M, Zhou S, Forrester
SG(2010): Association of ionchannel genotype and macrocyclic lactone sensitivity traits in Haemonchus contortus. Mol. Biochem. Parasitol., 171(2): 74- 80.

34- Ros-Moreno RM, MorenoGuzmán MJ, JiménezGonzález A and RodriguezCaabeiro F(1399): Interaction of ivermectin with gammaaminobutyric acid receptors in Trichinella spiralis muscle larvae. Parasitol. Res., 85(4): 320- 3.

35- Artis D, Grencis RK(2008): The intestinal epithelium: sensors to effectors in nematode infection. Mucosal Immunol., 1(4): 252-64.

36- Gagliardo LF, McVay CS, Appleton JA(2002): Molting, ecdysis, and reproduction of Trichinella spiralis are supported in vitro by intestinal epithelial cells. Infect. Immun., 70(4): 1853-9.

37- Romaris F, Appleton JA(2001): Invasion of epithelial cells by Trichinella spiralis: in vitro observations. Parasite 8(2 Suppl.) : S 48-S50.

38- Romaris F, North SJ, Gagliardo LF, Butcher BA, Ghosh K, Beiting DP, Panico M, Arasu P, Dell A, Morris HR, Appleton JA (2002): A putative serine protease among the excretory-secretory glycoproteins of L1 Trichinella spiralis. Mol. Biochem. Parasitol., 122(2): 14960.

39- Jung HC, Eckmann L, Yang SK, Panja A, Fierer J, Morzycka-Wroblewska E, Kagnoff MF(1995): A distinct 
array of proinflammatory cytokines is expressed in human colon epithelial cells in response to bacterial invasion. J. Clin. Invest., 95(1):55- 65.

40- Stadnyk AW and Kearsey JA (1996): Pattern of proinflammatory cytokine mRNA expression during Trichinella spiralis infection of the rat. Infect. Immun., 64(12): 5138-5143.

41- Stadnyk AW, Dollard CD, Issekutz AC(2000): Neutrophil migration stimulates rat intestinal epithelial cell cytokine expression during helminth infection. J. Leuk. Biol., 68(6):821-7.

42- Yang SK, Eckmann L, Panja A, Kagnoff MF(1997): Differential and regulated expression of $\mathrm{C}-\mathrm{X}$ $\mathrm{C}, \mathrm{C}-\mathrm{C}$ and $\mathrm{C}$-chemokines by human colon epithelial cells. Gastroenterol., 113(4):12141223.

43- Stadnyk A, Waterhouse C. Epithelial cytokine in intestinal inflammation and mucosal immunity. Current Opinion Gatroenterology 1997; 13: 510517.

44- Keating C, Pelegrin P, Martínez CM, Grundy D(2011): P2X7 receptordependent intestinal afferent hypersensitivity in a mouse model of postinfectious irritable bowel syndrome. J. Immunol., 187(3): 1467- 74.

45- Despommier DD(1993): Trichinella spiralis and the concept of niche. J. Parasitol., 79(4): 472-82.

46- Pelegrin P, Barroso- Gutierrez C, Surprenant A(2008): P $2 X 7$ receptor differentially couples to distinct release pathways for IL-1 beta in mouse macrophage. J. Immunol., 180(11): 7147- 57.

47- Jackson JA, Turner JD, Rentoul L, Faulkner H, Behnke JM, Hoyle M, Grencis RK, Else KJ, Kamgno J, Boussinesq $M$, Bradley JE(2004): T helper cell type 2 responsiveness predicts future susceptibility to gastrointestinal nematodes in humans. J. Infect. Dis., 190(10):1804-11.

48- Shen L, Turner JR(2006): Role of epithelial cells in initiation and propagation of intestinal inflammation. Eliminating the static: tight junction dynamics exposed. Am. J. Physiol. Gastrointest. Liver Physiol., 290(4): G577- 82.

49- Li CG, Rand MJ(1990): Nitric oxide and vasoactive intestinal polypeptide mediate nonadrenergic, non-cholinergic inhibitory transmission to smooth muscle of the rat gastric fundus. Eur. J. Pharmacol., 191: 303-9.

50- Arciszewski MB, Nowakowski Z, Wasowicz k, Calka J(2009): Expression of vasoactive intestinal polypeptide, substance $\mathrm{P}$ and neuropeptide $\mathrm{Y}$ in jejunal enteric nerves is altered in rabbits suffering from long term Trichinella spiralis infection: an immunohistochemical study. Veterinar. Medicina 54(12): 58997.

51- Sharkey KA, Mawe GM(2002): Neuroimmune and epithelial interactions in intestinal inflammation. Curr. Opin.Pharmacol., 2(6): 669-77. 
52- Palmer JM, Wong-Riley M, Sharkey KA(1998): Functional alterations in jejunal myenteric neurons during inflammation in nematode-infected guinea pigs. American J. Physiol. Gastrointest. Liver Physiol., 275(5 Pt. 1): 92235.

53- Furness $\mathbf{J B}(\mathbf{2 0 0 8})$ : The enteric nervous system: normal functions and enteric neuropathies..J. Neurogastroenterol. Motil., 20(Suppl .1): 32-38.

54- Ganea D(1996): Regulatory effects of vasoactive intestinal peptide on cytokine production in central and peripheral lymphoid organs. Adv. Neuroimmunol., 6(1):61-74.

55- Serna H, Porras $M$, Vergara P(2006): Mast cell stabilizer ketotifen [4-(1-methyl-4piperidylidene)-4h-benzo [4, 5]cyclohepta [1,2-b] thiophen$10(9 \mathrm{H})$ - one fumarate] prevents mucosal mast cell hyperplasia and intestinal dysmotility in experimental Trichinella spiralis inflammation in the rat. J. Pharmacol.Exp. Ther., 319(3):1104-11.

56- Enoksson M, Lyberg K, MollerWesterberg C, Fallon PG, Nilsson G, LunderiusAndersson C(2011): Mast cells as sensors of cell injury through IL-33 recognition. J. Immunol., 186(4): 2523- 8.

57- Wood J(2007): Effects of bacteria on the enteric nervous system: implications for irritable bowel syndrome. J. Clin. Gastroenterol., 41(Suppl.1): S719.
58- Pozo D, Delgado M(2004): The many faces of VIP in neuroimmunology: a cytokine rather a neuropeptide? FASEB., 18(12): 1325-34.

59- Sann H, Erichsen Jv, Hessmann M, Pahl A, Hoffmeyer A(2013): Efficacy of drugs used in the treatment of IBD and combinations thereof in acute DSS-induced colitis in mice. Life Sci., 92(12):708-18.

60- Derda M, Hadas E(2000): Antioxidants and proteolytic enzymes in experimental trichinellosis. Acta Parasit., 45(4): 356-61.

61- Bercik P, Wang L, Verdu EF, Mao YK, Blennerhassett $P$, Khan WI, Kean I, Tougas G, Collins SM. (2004): Visceral hyperalgesia and intestinal dysmotility in a mouse model of post-infective gut dysfunction. Gastroenterol., 127(1): 179-187.

62- Paul G, Bataille F, Obermeier F, Bock J, Klebl F, Strauch U, Lockbaum D, Rummele P, Farkas S, Scholmerich J, Fleck M, Rogler G, Herfarth H(2005): Analysis of intestinal heme-oxygenase 1 (HO-1) in clinical and experimental colitis. J. Clin.Gastroenterol., 140 (3): 547-55.

63- Dalle-Donne I, Aldini G, Carini M, Colombo R, Rossi R, Milzani A(2006): Protein carbonylation, cellular dysfunction, and disease progression. J. Cell. Mol. Med., 10(2): 389-406.

64- Ogino K, Wang DH. (2007): Biomarkers of oxidative/nitrosative stress: an 
approach to disease prevention. Acta Med. Okayama 61(4):18189.

65- Derda M, Wandurska-Nowak E, Hadaś E(2004): Changes in the level of antioxidants in the blood from mice infected with Trichinella spiralis. Parasitol. Res., 93(3): 207- 10.

66- El-Azzouni MZ(1997): Effect of ivermectin on experimental trichinosis. J. Egypt. Soc. Parasitol. 27(2):331-40.

67- Fu Y, Nie HM, Niu LL, Xie Y, Deng JB, Wang Q, Yang GY, Gu XB, Wang SX(2011):. Comparative efficacy of ivermectin and levamisole for reduction of migrating and encapsulated larvae of Baylisascaris transfuga in mice. Korean J. Parasitol.,49(2): 14551.

68- Satou T, Koga M, Koike K, Tada I, Nikaido T(2001): Nematocidal activities of thiabendazole and ivermectin against the larvae of Strongyloides ratti and $S$. venezuelensis. Vet. Parasitol., 99(4):311-22.

69- Klager S, Whitworth JA, Post RJ, Chavasse DC, Downham MD(1993): How long do the effects of ivermectin on adult Onchocerca volvulus persist?
Trop. Med. Parasitol., 44(4): 305 310.

70- Ottesen EA, Hooper PJ, Bradley M, Biswas G(2008): The global program to eliminate lymphatic filariasis: Health impact after 8 years. PLoS Negl. Trop. Dis., 2(10): e317-28.

71- Yates DM, Wolstenholme AJ(2004): An ivermectinsensitive glutamate-gated chloride channel subunit from Dirofilaria immitis. Int. J. Parasitol., 34(9):1075- 81.

72- Beech RN,Wolstenholme AJ,Neveu C,Dent JA,(2010): Nematode parasite genes.: What's in a name? Trends Parasitol., 26(7): $334-340$.

73- Youssef FG, Hassanein MS, Abdel Fattah MS, ElSharkawy IM(1997): Effect of two single doses of ivermectin in treatment of asymptomatic bancroftian filariasis in two villages in the Nile Delta, Egypt. J. Egypt. Soc. Parasitol., 27(1): 83-92.

74- Androbicos NM, McNally J, Kotze AC, Hunt PW, Ingham A(2012): $\quad$ Trichostrongylus colubriformis larvae induce necrosis of IL-33 from intestibal epithelial cells in vitro: Implications for gastrointestinal nematode vaccine design. Int.J. Parasitol., 42(3): 295-304. 


\section{التعبير عن بعض السيتوكينات الموالية للالتهابات وبعض عوامل الالتهاب في النموذج التجريبي من الثعرينة الحلزونية}

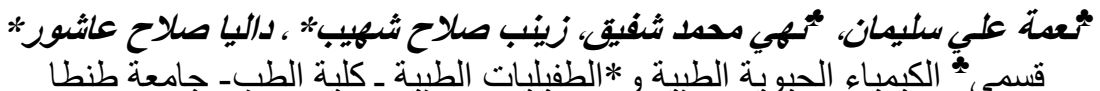

الخيطيات هو حيو اني المنثأ التي حصل عليها ابتلاع اللحوم غير المطبوخة جيدة التيدا التي تحتوي

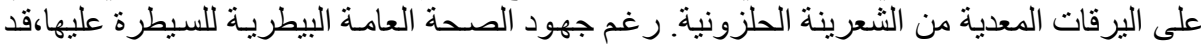

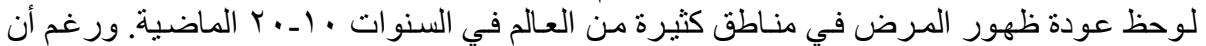

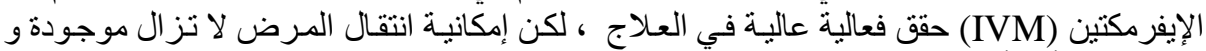

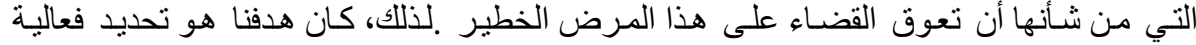

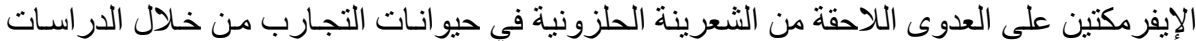

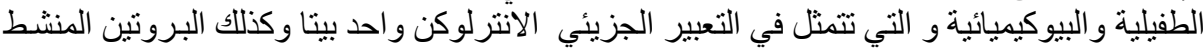

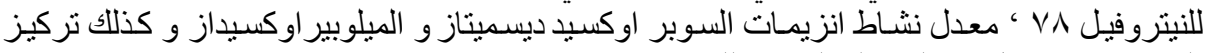
البروتين كاربونيل في المرحلة المعوية للعدوي.

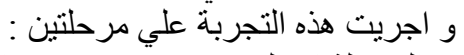

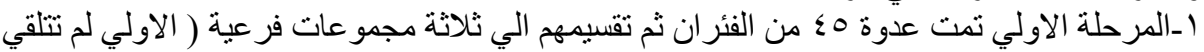

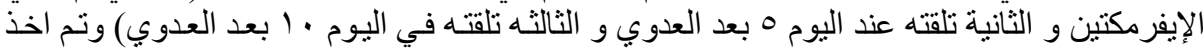

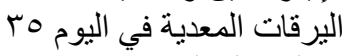

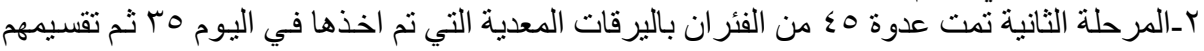

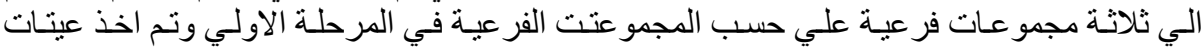

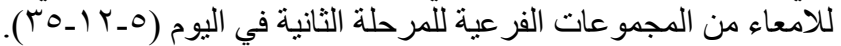

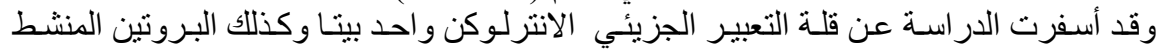
VA اللنيتروفيل و كنلك معدل نثاط انزيمات السوبر اوكسيد ديسميتاز و الميلوبير اوكسيداز وتركيز البروتين كاربونيل

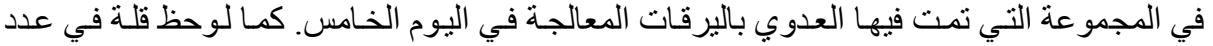

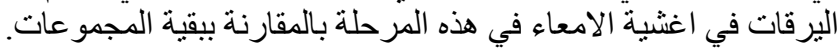
هذه النتائج تعكس مدي فاعلية و قدرة الإيفرمكتين كعلاج و ذللك عند استخدامه في مر احل متقدمة من العلاج. 